\title{
Review
}

\section{Food-intake regulation during stress by the hypothalamo-pituitary-adrenal axis}

\author{
${ }_{4}$ Q1 Nadezhda Bazhan ${ }^{\mathrm{a}, *}$, Dóra Zelena ${ }^{\mathrm{b}}$ \\ a Institute of Cytology and Genetics, Russia Academy of Sciences, Novosibirsk, Russia \\ ${ }^{\mathrm{b}}$ Institute of Experimental Medicine, Hungarian Academy of Sciences, Budapest, Hungary
}

\section{A R T I C L E I N F O}

\section{Article history:}

Received 2 November 2012

Received in revised form 14 March 2013

Accepted 8 April 2013

Available online $\mathrm{xxx}$

\section{Keywords:}

Stress

CRH

ACTH

Glucocorticoid

Food intake regulation

Obesity

\begin{abstract}
A B S T R A C T
The prevalence of obesity is increasing worldwide with serious consequences such as diabetes mellitus type 2 and cardiovascular diseases. Emotional stress is considered to be one of the main reasons of obesity development in humans. However, there are some contradictory results, which should be addressed. First of all stress induces anorexia, but not overeating in laboratory animals. Glucocorticoids, the effector molecules of the hypothalamo-pituitary-adrenocortical (HPA) axis stimulate and stress inhibits food intake. It is also not clear if stress is diabetogenic or an antidiabetogenic factor. The review will discusses these issues and the involvement of the whole HPA axis and its separate molecules (glucocorticoids, adrenocorticotropin, corticotropin-releasing hormone) in food intake regulation under stress.
\end{abstract}

(c) 2013 Published by Elsevier Inc.

1. Introduction

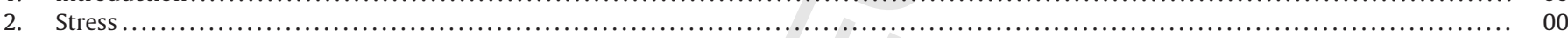

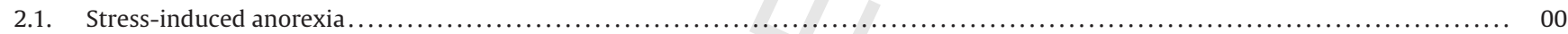

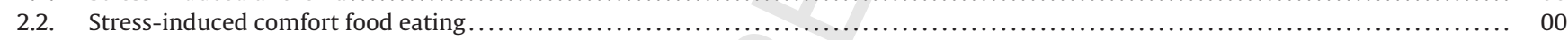

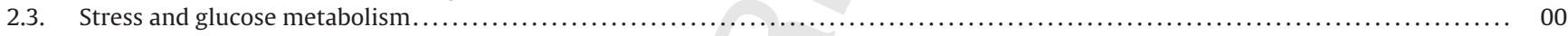

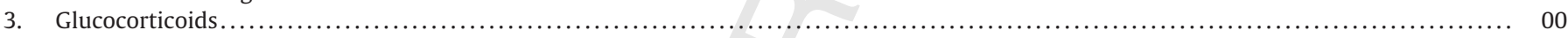

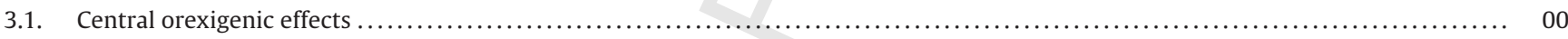

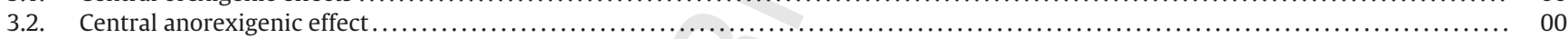

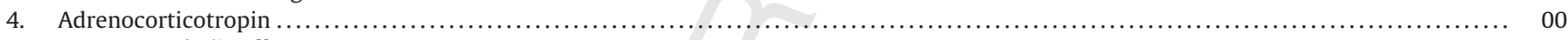

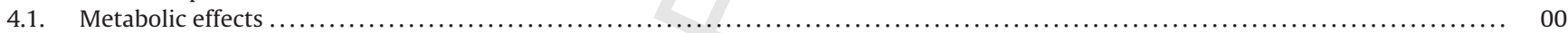

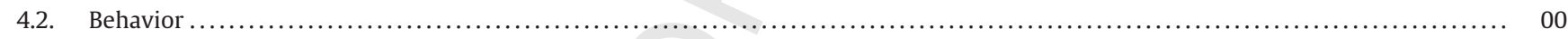

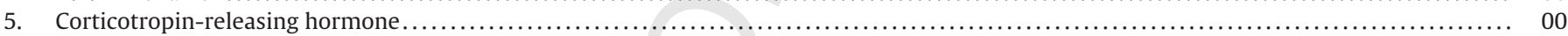

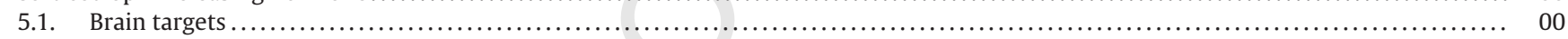

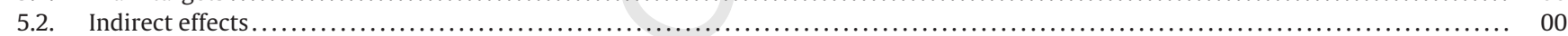

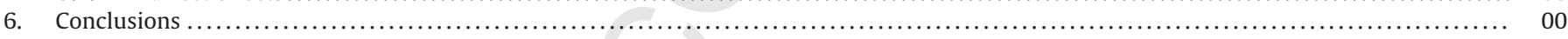

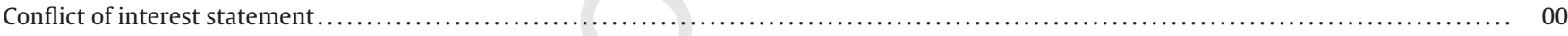

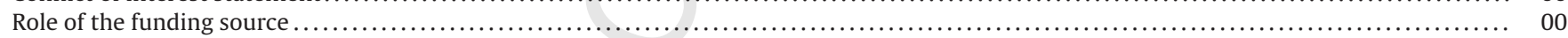

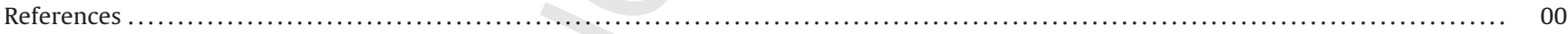

\footnotetext{
* Corresponding author at: Institute of Cytology and Genetics, The Siberian Branch of the Russian Academy of Sciences, 630090 Novosibirsk, Prospekt Lavrentyeva 10, Russia. Tel.: +7 8383363 4971; fax: +7 3833331278 .

E-mail address: bazhan-nm@yandex.ru (N. Bazhan).
}

0361-9230/\$ - see front matter @ 2013 Published by Elsevier Inc. http://dx.doi.org/10.1016/j.brainresbull.2013.04.002 


\section{Introduction}

The prevalence of obesity is increasing worldwide with serious consequences such as diabetes mellitus type 2 (DM2) and cardiovascular diseases (Caballero, 2007). At the same time people in the developed countries are facing more stress, which might be one of the contributing factors for the development of obesity (Adam and Epel, 2007; Greeno and Wing, 1994; Nieuwenhuizen and Rutters, 2008; O'Connor and Conner, 2011). However, the stress-eatingobesity relationship is complicated (Moore and Cunningham, 2012). First of all, among experimental conditions stress induces anorexia, while in humans stress-induced obesity is more prevalent. In line with these observation glucocorticoids (GCs), the effector molecules of the hypothalamo-pituitary-adrenocortical axis (HPA or stress axis, Fig. 1) stimulate (Bartolomucci et al., 2009; Bjorntorp, 2001; King and Smith, 1985), while stress, as a whole, inhibits food intake (Bazhan et al., 2007; De Souza et al., 2000; Harris et al., 2001; Krahn et al., 1990; Rybkin et al., 1997). It is also not clear if stress is diabetogenic (Rosmond, 2003; Surwit et al., 1992) or an antidiabetogenic factor (Bates et al., 2008a,b; Kai et al., 2000).

Although GCs are the end hormones of the HPA axis, we assume that other components of the axis could also have a role in food intake regulation during stress (Fig. 1). Of course other systems could have been taken into consideration, like the stress-induced increase in sympatho-adrenomedullary activity or the serotoninergic system, but in our minireview we will focus on the molecules of the HPA axis. In the following we will summarize participation of stress, its end hormone (GCs), hypophyseal (adrenocorticotropin, ACTH) and hypothalamic components (corticotropin-releasing hormone, $\mathrm{CRH}$ ) in food intake regulation, which is one of the crucial components of obesity.

\section{Stress}

$\mathrm{CRH}$, originally characterized in the nucleus paraventricularis hypothalami (PVN) as the principal regulator of the HPA axis, has broad central and peripheral distribution and actions. CRH-1

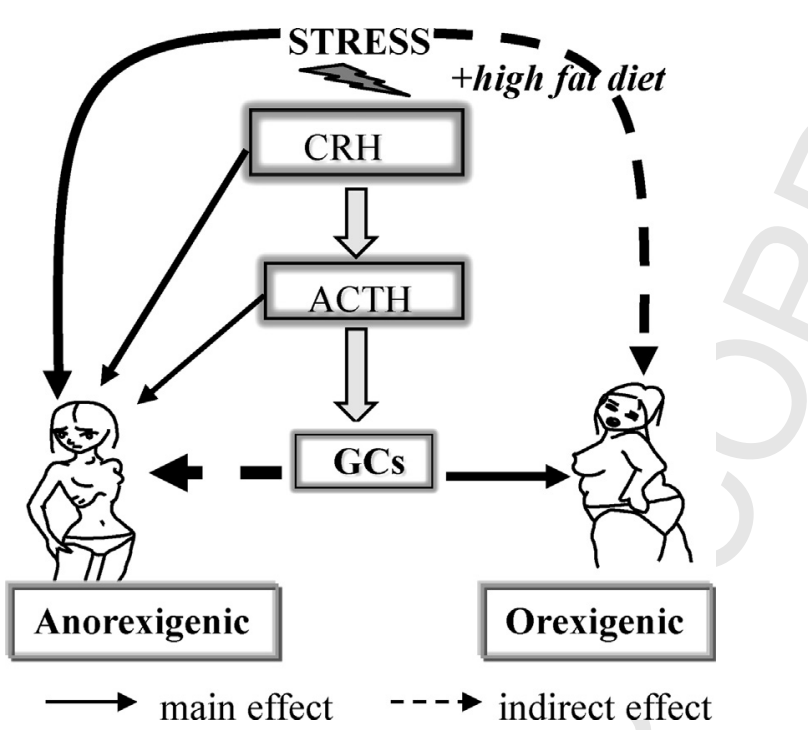

Fig. 1. Possible contribution of the molecules of the hypothalamo-pituitaryadrenocortical axis to food intake regulation. Stress per se is anorexigenic. However, in combination with comfort food it might induce obesity. In this respect glucocorticoids are very important. They exert orexigenic effect among rest, but the anorexigenic factors may overcome their effect during stress. However, in the presence of high calorie diet the addictive potential of glucocorticoid may come into highlight and strongly contribute to development of obesity. CRH, corticotropinreleasing hormone; ACTH, adrenocorticotropin; GCs, glucocorticoids. and $\mathrm{CRH}-2$ receptors relay signals from $\mathrm{CRH}$ and its paralogues urocortins (Ucn) (Kuperman and Chen, 2008). CRH-1 receptor is expressed on anterior pituitary corticotropes and induces the synthesis of ACTH from proopiomelanocortin (POMC) precursor in response to hypothalamic CRH (Vale et al., 1981). This release leads to the downstream secretion of GCs from the adrenal cortex via melanocortin 2 (MC-2) receptors. The endhormones of the axis, GCs have widespread effects through ubiquitous intracellular glucocorticoid receptor (GR), which could be found on most cells and tissues, and through another intracellular steroid receptor, the mineralocorticoid receptor (MR), which is more abundant in the hippocampus and regulates negative feedback on the HPA axis (Chrousos, 2000). Among others GCs stimulate the gluconeogenesis in the liver to increase circulating glucose levels.

There are several studies on the effect of stress on food-intake without dissecting a single molecule. Thus, in these cases we might assume the involvement of the molecules of the whole HPA axis, not only GCs, but also ACTH and CRH.

\subsection{Stress-induced anorexia}

Emotional stress is known to suppress appetite in humans (Fryer et al., 1997) and laboratory rodents (Bazhan et al., 2007; De Souza et al., 2000; Harris et al., 2001; Krahn et al., 1990; Rybkin et al., 1997) (Table 1 and Fig. 1). The stress-induced reduction in food intake has been demonstrated both as an acute response after a single stress and as a maintained decrease in $24 \mathrm{~h}$ food intake during and after repeated daily restraint stress (Krahn et al., 1990; Shimizu et al., 1989). Moreover, once stress has ended, restrained rats fail to return to normal weight (Bazhan et al., 2007; Levin et al., 2000; Rybkin et al., 1997).

Central mechanisms involved in the stress-induced inhibition of food intake have not been fully elucidated, but certain brain areas were already suggested to have a role. The major central nervous system structure involved in food-intake regulation is the hypothalamus (especially the ventromedial hypothalamus (VMH), lateral hypothalamus, PVN and nucleus arcuatus (ARC)) (Palkovits, 2003; Schwartz et al., 2000) being the center of stress response, too. Indeed, hypothalamic CRH and melanocortin systems are well recognized to connect stress with anorexia in rodents (Ohata and Shibasaki, 2011). CRH system is a mediator of the appetitesuppressing effects of stress also in fish (Bernier, 2006).

Other brain areas, like amygdala (Holsen et al., 2012; Solomon et al., 2010), dorsal vagal complex (Charrier et al., 2006) and dorsal raphe (Holsen et al., 2012), may contribute to stress-induced anorexia without affecting the HPA axis activity.

\subsection{Stress-induced comfort food eating}

Anorexia induced by acute and repeated restraint stress was followed by increased proportion of comfort food eating (with high fat/sugar contents) (Dallman, 2010; Dallman et al., 2005; Foster et al., 2009; la Fleur et al., 2005; Pecoraro et al., 2004). In contrast to normal diet, when sweet food was presented to the stressed animals repeated mild pinch resulted in hyperphagia and considerable gain in body weight (Rowland and Antelman, 1976) (Table 1). Chronic life stress seems to be associated with a greater preference for energy- and nutrient-dense foods (Torres and Nowson, 2007). During the course of prolonged/repeated food intake the sensoryspecific satiety (SSS) can reduce the intake of the same food. Stressors may induce a disruption of this signal, thereby resulting in a relative increase in consumption of the same food (Ahn and Phillips, 2012). Comfort food per se might have similar effect. E.g. in an unstressed human population habituation could develop to SSS effect of the same, although palatable diet (Tey et al., 2012). Development of obesity to monotonous high fat diet in animals (DIO 
Table 1

Q4 Effects of stress on the food intake.

\begin{tabular}{|c|c|c|}
\hline High calorie food & Is not available & Is available \\
\hline Food intake & $\begin{array}{l}\text { Anorexia (Bazhan et al., 2007; De Souza et al., 2000; Fryer et al., } \\
\text { 1997; Harris et al., 2001; Krahn et al., 1990; Rybkin et al., 1997) }\end{array}$ & $\begin{array}{l}\text { Hyperphagia (Dallman, 2010; Dallman et al., 2005; Foster et al., } \\
\text { 2009; la Fleur et al., 2005; Pecoraro et al., 2004) }\end{array}$ \\
\hline Mechanisms & $\begin{array}{l}\text { Stress induces anorexia due to decreased signaling of: } \\
\text { AgRP (Chagra et al., 2011; Kas et al., 2005) } \\
\text { NPY (Tempel and Leibowitz, 1994; White, 1993) } \\
\text { due to increased signaling of: } \\
\text { insulin? (Chavez et al., 1997; Warne, 2009) } \\
\text { leptin? (Dagogo-Jack et al., 1997; Miell et al., 1996; Newcomer } \\
\text { et al., 1998; Slieker et al., 1996; York, 1996) } \\
\text { CRH and Ucn } 3 \text { (Bernier, 2006; Ohata and Shibasaki, 2011; Smagin } \\
\text { et al., 1998) } \\
\text { CART (Kask et al., 2000; Xu et al., 2010) } \\
\text { Nesfatin-1 (Goebel et al., 2009; Stengel et al., 2011) } \\
\text { NPW (Beck et al., 2010) } \\
\text { Melanocortins (Liu et al., 2007; Yamano et al., 2004) } \\
\text { central monoaminergic systems (Gibson, 2006) } \\
\text { autonomous nervous system (Seematter et al., 2004) }\end{array}$ & $\begin{array}{l}\text { Stress induces hyperphagia due to reduction of: } \\
\text { sensor specific satiety (Ahn and Phillips, 2012; Ortolani et al., 2011) } \\
\text { stressor aversiveness (Piazza and Le Moal, 1997) } \\
\text { CRH signaling? (Foster et al., 2009; la Fleur et al., 2005; Pecoraro } \\
\text { et al., 2004) } \\
\text { due to activation of central reward pathways (Piazza and Le Moal, } \\
\text { 1997), } \\
\text { due to alterations in gut microbiota (Tehrani et al., 2012) } \\
\text { Glucocorticoids induce hyperphagia (Dallman, 1993; Drapeau et al., } \\
\text { 2003; Epel et al., 2000; Tataranni et al., 1996) } \\
\text { due to increased signaling of: } \\
\text { NPY (Gyengesi et al., 2010; Krysiak et al., 1999; McKibbin et al., } \\
\text { 1992; White et al., 1994; Wilding et al., 1993), } \\
\text { AgRP (Coll et al., 2005; Savontaus et al., 2002), } \\
\text { Nociceptin (Green and Devine, 2009; Nativio et al., 2011; } \\
\text { Olszewski and Levine, 2004); }\end{array}$ \\
\hline
\end{tabular}

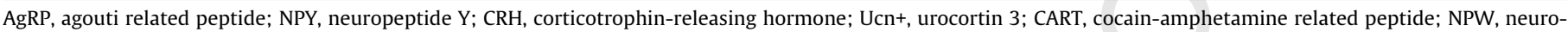
peptide $W$.

model) suggests a similar habituation to the SSS effect in rodents (Auvinen et al., 2011; Ryan et al., 2012). Moreover, rats submitted to footshock stress decreased the intake of commercial chow, but kept unaltered the intake of comfort food (Ortolani et al., 2011).

According to Dallman, energy stores are critically important for normal activity in the central stress-response network (Dallman, 2010). When a chronic stressor results in high GCs levels, the steroids act in brain in a feed-forward fashion to recruit a stress-response network that biases ongoing autonomic, neuroendocrine, and behavioral outflow as well as responses to novel stressors (Dallman et al., 2006). When rats are allowed to eat fat or sucrose under acute or repeated restraint stress, CRH expression in the hypothalamus and bed nucleus of stria terminalis (BNST), as well as ACTH and GC secretion are reduced (Foster et al., 2009; la Fleur et al., 2005; Ortolani et al., 2011; Pecoraro et al., 2004).

On the other hand, increased ingestion of palatable foods during and after stressors may simply reflect a pleasurable activity that reduces the discomfort of stress. Eating a meal alters mood and emotional predisposition, typically reducing arousal and irritability, and increasing calmness and positive affect (Gibson, 2006). Since food intake has reinforcing effects, we can assume that severe obesity and addiction disorders share, at least in parts, common neuronal circuits (Berridge, 2009; Kiefer and Grosshans, 2009; Volkow et al., 2008). Indeed, eating of high calorie food is known to counteract some effects of stress, probably via the same mechanism as in alcoholics (Kiefer and Grosshans, 2009). Chronic stress has been known to potentiate addictive behaviors in both human addicts and experimental animals (Stamp et al., 2008). By stimulating central reward pathways, high levels of corticosterone (the main GC in rodents) can reduce the aversiveness of the stressor (Piazza and Le Moal, 1997).

Another possible mechanism, how stress can affect obesity is the bidirectional interaction between HPA axis and the gastrointestinal tract (Dinan and Cryan, 2012; Sudo, 2012). Stressor exposure induces negative changes in several gastrointestinal parameters including microbiota (Konturek et al., 2011). Alteration in gut microbiota may be an initial event leading to altered feeding behavior than to weight gain and metabolic syndrome (Tehrani et al., 2012). High-calorie diet has been also associated with changes in the gut microbiota in mice and in humans, thus stressor-induced comfort food intake can induce obesity also through an influence on microbiome (Pedersen et al., 2013).

Taken together, the scheme proposed by Dallman is very simple: stress induces comfort food eating and comfort food eating reduces stress (Dallman et al., 2005). Although we should take into consideration the rewarding nature of meal, Dallman's theory on the stress-induced palatable eating is of great importance for understanding mechanisms of obesity development. However, it concerns only human, since animals cannot prefer "palatable food" in the wild nature. Despite the more prevalent stress-induced obesity in human, there is no animal model, where single or repeated stress exposure leads to development of obesity under normal diet. GCs may potentiate the development of obesity and other aspects of metabolic syndrome only in those animals, which fed a high calorie, fat or sugar diet during the stress (Rasmusson et al., 2010). Thus, stress per se, without high calorie input does not result in obesity. Although this idea is not really new, but should be emphasized since changes in eating behavior seem to be an essential tool in the fight against obesity.

\subsection{Stress and glucose metabolism}

It is well known that acute stress induces temporary elevation in blood glucose levels, although this acute increase maybe due mostly to sympathetic activation (Seematter et al., 2000). Nevertheless, a rise in peripheral blood glucose concentration inhibits the appetite (Blazquez Fernandez, 2003; Burdakov et al., 2005).

On the other hand, prolonged stress-induced excess of GCs may lead to hyperphagia (Drapeau et al., 2003), thereby to obesity and insulin resistance together with hyperglycaemia leading to development of DM2 (Rosmond, 2003; Surwit et al., 1992). In this case the hypophagic effect of high glucose levels cannot be detected as the insulin resistance prevents glucose action on the neurons involved in the food intake regulation.

On the contrary, adaptation to intermittent restraint stress (Bates et al., 2008a,b) and immobilization (Kai et al., 2000) delays development of hyperglycemia and hyperinsulinemia (Bazhan et al., 2007) in rodent genetic models of DM2. It is partially due to stress-induced anorexia that likely improves insulin sensitivity and maintains $\beta$-cell compensation (Bates et al., 2008a,b; Kelley et al., 1993). Another possible mechanism is the intermittent stressinduced adaptations that reduce the hyperglycemic effect of GCs (Bates et al., 2008a,b).

Importantly, these later findings contrast with common view that all stressors are deleterious for diabetes and illustrate that intermittent exposure to stressors and the ensuing adaptations 
222 may instead be important for normal physiological functioning by 223 preparing the body to deal with threats to homeostasis.

\section{3. Glucocorticoids}

Although there are many functions related to GCs from permissive one till stimulations (Sapolsky et al., 2000), but till now we do not know what is the exact role of stress-induced elevation of GCs (Vinson, 2009). Perhaps the first described role, the regulation of the blood glucose levels is the most important one. GCs stimulate glucose output from the liver by inducing gluconeogenic enzymes and by mediating, through their metabolic action on muscle, the provision of the gluconeogenic substrate.

Since abdominal adipose tissue has more cells per mass units, higher blood flow and more GC receptors, GCs affect abdominal fat to a greater extent than subcutaneous adipose tissue (Drapeau et al., 2003). Therefore it is likely that some types of abdominal obesity may be due to increased GC access (Dallman et al., 1995). Cushing's syndrome is the best evidence. A mutation of the corticosterone-binding globulin with increased free GC levels has been also associated with a higher waist-to-hip ratio and a higher risk on obesity development (Barat et al., 2005; Joyner et al., 2003). The abdominal obesity is specially important as obese with a more peripheral body fat distribution does not show health risk markers (Nieuwenhuizen and Rutters, 2008).

Under normal physiological conditions, endogenous GCs may have a primary function in controlling nutrient ingestion and metabolism over the natural circadian cycle (Tempel and Leibowitz, 1994). Low basal levels of circulating corticosterone tonically activate MRs leading to fat ingestion and deposition. In contrast, GRs are phasically activated during the circadian or stressor-induced peak of GCs. Activation of this receptor is required for carbohydrate ingestion which provides additional substrate for glucose homeostasis thereby ensuring energy to stress. Through these actions GCs have impact on total calorie intake and on long-term regulation of body weight. There are many polymorphisms both of GR and MR with enhanced GC effects, which are associated with obesity (Nieuwenhuizen and Rutters, 2008).

\subsection{Central orexigenic effects}

Although GCs are primarily catabolic at the periphery (lipolysis, proteolysis, but glycogenesis), they have anabolic effects in the central nervous system (CNS) (Dallman et al., 1995), where they act to increase food intake (Drapeau et al., 2003; Tempel et al., 1992) (Fig. 1). Appetite in humans and animals follows changes in adrenal steroid levels. Anorexia and weight loss are hallmarks of adrenal insufficiency in Addison's disease, whereas increased appetite correlates with GC overproduction in Cushing's syndrome and with exogenous GC administration in normal volunteers (Tataranni et al., 1996). In women experimental stressinduced cortisol secretion increased appetite and craving for sugar (Epel et al., 2000). Adrenalectomy (ADX, surgical removal of the adrenals) or GC treatment, respectively, prevent or restore weight gain in both normal rodents and many models of genetic or experimentally induced obesity, often through an effect on food intake (Dallman, 1993; Jacobson, 1999; Santana et al., 1995; Tokuyama and Himms-Hagen, 1989).

Besides a possible direct effect GCs may promote food consumption through stimulation of orexigenic hypothalamic neuropeptides like neuropeptide $\mathrm{Y}$ (NPY) and agouti related peptide (AgRP) (Gyengesi et al., 2010) (Table 1). ADX reduces the number of excitatory synapses onto NPY/AgRP neurons (Gyengesi et al., 2010), and decreases NPY and AgRP gene expressions in the medial basal hypothalamus in rats (Savontaus et al., 2002). All of these changes were reversed by GC replacement (Gyengesi et al., 2010). In addition, GCs produce an increase of NPY mRNA and protein in the ARC (Wilding et al., 1993) and in PVN (Krysiak et al., 1999; McKibbin et al., 1992) in rats. Different stressors such as brief session of inescapable foot shocks and 1-h restraint increase NPY mRNA levels in the ARC of rats (Conrad and McEwen, 2000; Kas et al., 2005).

Nociceptin/orphanin, a peptide closely related to dynorphin $A$, moderately increases food intake under various conditions (Olszewski and Levine, 2004). Both stress (restraint) and GC administration increase the level of nociceptin in the hippocampus (Nativio et al., 2011). Stress induced by social defeat elevated the mRNA level of nociceptin receptor in the PVN (Green and Devine, 2009).

On the other hand, GCs may inhibit the release of the anorexigenic signals like CRH (Foster et al., 2009; la Fleur et al., 2005; Pecoraro et al., 2004). The picture is even more complicated as it was proposed that GCs increased orexigenic hypothalamic NPY concentrations and NPY gene expression via both direct mechanisms and indirectly through inhibition of the CRH system (Cavagnini et al., 2000). However, genetic CRH deficiency neither augmented basal food intake nor attenuated decreases in feeding after ADX, furthermore, restoration of food intake in ADX mice by GCs did not depend on inhibition of CRH (Jacobson, 1999). These results suggest that, at least in mice, factors other than or in addition to CRH are more important for controlling basal and GC associated effects on food intake.

\subsection{Central anorexigenic effect}

Our assumption is that primary effect of GCs is orexigenic and anorexigenic effects are secondary. However, the orexigen effect of GCs is expressed only in nonstress conditions, as during stress inhibition of food intake obscures it, despite the dramatically high plasma GC concentrations (Bazhan et al., 2007; De Souza et al., 2000; Harris et al., 2001; Krahn et al., 1990; Rybkin et al., 1997). It is not entirely clear, what shifts the behavioral outcome of orexigenic GC administration to anorexigenic stress-induced GC elevation.

One possible target could be the NPY/AgRP neurons. Although GC administration stimulates both orexigenic neuropeptides (see earlier), but during stressful events their expressions are differentially regulated (Kas et al., 2005). More precisely, acute and repeated restraint reduces the number of AgRP-expressing cells (Chagra et al., 2011), and brief session of inescapable foot shocks down-regulates AgRP mRNA levels in ARC in the rat hypothalamus (Kas et al., 2005). AgRP is known to be the natural antagonist for the type 4 melanocortin (MC-4) receptors mediating anorexigenic signals of melanocortins (Leibowitz and Wortley, 2004). Stress-induced reduction in AgRP expression may contribute to food intake inhibition through activation of melanocortin signaling. Indeed, melanocortinergic pathway can be rapidly recruited by acute emotional stress (Liu et al., 2007).

Previous studies considered the elevation of insulin as the most important anorexigenic factor during stress. It is known that exogenous GCs stimulate insulin production in ADX rats (Warne, 2009) and ADX increases sensitivity to the effect of central insulin administration to reduce food intake (Chavez et al., 1997). However, we should mention, that restraint stress does not increase, but decreases insulin levels (Kiba, 2004; Macho et al., 1999; Nonogaki, 2000). Moreover, stressors-induced adrenal epinephrine and sympathetic norepinephrine release is known to inhibit insulin secretion (Kiba, 2004; Nonogaki, 2000). Therefore other mechanisms should be considered.

An elevation in plasma leptin levels is also anorexigenic (Ortolani et al., 2011; Won et al., 2009; Zareian et al., 2011). GCs can interact with leptin in the long-term regulation of energy intake and body adiposity. For example, hyperphagia in animals with leptin 
or leptin receptor deficiency is attenuated by ADX (York, 1996), supraphysiological doses of exogenous GCs increase leptin mRNA levels in ob/ob mice, leptin secretion in cultured rat adipocytes (Slieker et al., 1996), and circulating leptin concentrations in normal and obese humans (Dagogo-Jack et al., 1997; Miell et al., 1996; Newcomer et al., 1998). But these authors did not measure food intake, and it remains unknown whether GC-induced hyperleptinemia is followed by anorexia in humans. Moreover, acute elevation of plasma GCs, in a physiological range, induced with central pharmacological or physiological stimuli (stress, naloxone, vasopressin and/or CRH) does not appear to influence plasma leptin concentrations in humans (Nye et al., 2000; Tataranni et al., 1997) and adipose leptin gene expression in rats (Rybkin et al., 1997). Thus, further studies are required to determine whether GCs can inhibit food intake during stress by stimulating plasma leptin levels (Leal-Cerro et al., 2001).

We assume that orexigenic effects of GCs are not expressed in response to acute and chronic stresses in laboratory rodents, because they are counteracted by other stress-induced anorexigenic mechanisms, which are not dependent on the increased GC levels, e.g. melanocortin system, CRH and Ucn 3 signaling (Bernier, 2006; Ohata and Shibasaki, 2011; Smagin et al., 1998), cocaineand amphetamine-regulated transcript (CART) (Kask et al., 2000; Xu et al., 2010), nesfatin-1 (Goebel et al., 2009; Stengel et al., 2011), neuropeptide W (NPW) (Beck et al., 2010), melanocortins (Liu et al., 2007; Yamano et al., 2004) and others, but the exact mechanism is not clear (Table 1 ).

\section{Adrenocorticotropin}

The importance as well as the bimodal effect of ACTH in obesity is demonstrated by the fact that autoantibodies against ACTH could be found in $74 \%$ of patients both with anorexia nervosa and bulemia nervosa (Fetissov et al., 2002). Moreover, a rare mutation in exon 2 of POMC, that causes ACTH insufficiency, has been associated with early-onset obesity (Krude et al., 1998). There is no information available concerning the involvement of pituitary and peripheral ACTH on the central mechanisms of food-intake regulation, but related effects could be detected at the periphery.

\subsection{Metabolic effects}

In normal animals injection of ACTH increased both plasma glucose and insulin levels. In contrast, in adrenalectomised rabbits ACTH administration further increased the ADX-induced insulinemia along with hypoglycemia. Therefore it is reasonable to conclude that ACTH through GCs increases glucose levels, while, through stimulation of the pancreatic secretion of insulin, decreases it (Lesault et al., 1991).

ACTH may increase local blood flow in the brown adipose tissue influencing fat metabolism (Kuroshima et al., 1968). Indeed, MC2 receptors are expressed in white and brown adipocytes both at the mRNA and protein levels (Iwen et al., 2008) and ACTH stimulates free fatty acid release from epigastric adipose tissue of rabbits (Lewis and Matthews, 1968). Thus, ACTH has a direct lipolytic activity - present also in ADX rats - however, this effect is substantially lower than that of GCs (Spirovski et al., 1975). Insulin-induced glucose uptake in white adipocytes is reduced by ACTH treatment, thereby here not only the indirect (through GCs), but also the direct effect of ACTH is antagonistic to insulin. Thus, ACTH directly promotes insulin-resistance and enhances energy combustion. Taken together, the ACTH-adipocyte interaction may contribute to dysregulated energy balance, insulin resistance and cardio-metabolic complications in obesity and metabolic syndrome, however this assumption is not fully confirmed, yet.

\subsection{Behavior}

In the hypothalamus, proopiomelanocortin (POMC)-derived peptides, $\alpha$-MSH and ACTH, play a central role in the regulation of food intake via MC-4 receptor (Gantz et al., 1993). A potential role for ACTH in energy homeostasis is supported by observations that ACTH has a similar potency to $\alpha$-MSH at the MC- 4 receptor in vitro (Gantz et al., 1993), ACTH is secreted by the neurons of PVN (Pritchard et al., 2003), and ACTH can inhibit feeding when administered centrally to rats (Al-Barazanji et al., 2001). Single and repeated injections of $\mathrm{ACTH}$ antibodies into PVN resulted in persistently increased food intake during the light period. These data demonstrate extra-hormonal effects of ACTH and provide evidence that endogenous ACTH without further processing acts in the PVN to reduce food intake (Schulz et al., 2010).

Some data indicate that acute stressors stimulate melanocortin signaling, e.g. electrical shock increases MC-4 receptor and POMC mRNA, restraint and forced swimming evoke neuronal activation of POMC neurons in rat and mouse hypothalamus (Liu et al., 2007; Yamano et al., 2004). These data suggest the possible involvement of the hypothalamic melanocortins, including ACTH, in the development of stress-induced anorexia.

\section{Corticotropin-releasing hormone}

It is generally accepted that decreased feeding in response to stress reflects an adaptive, defensive anorexia. Several investigators have attributed stressor-induced anorexia to activation of the CRHsystem. It is well established that CRH influences feeding behavior and mediates behavioral and physiological responses to stress not only in laboratory rodents (Krahn and Gosnell, 1989), but also in steeres (Yayou et al., 2011) and fishes (Kang et al., 2011). Intracerebroventricular administration of CRH in rats inhibits feeding behavior (Cullen et al., 2001). Chronic administration of CRH into the hypothalamus also decreases food intake and body weight gain in rats (Tempel and Leibowitz, 1994). Pharmacological activation of the hypothalamic $\mathrm{CRH}-2$ receptors results also in suppression of feeding (Fekete and Zorrilla, 2007). At this point Ucn 1 and Ucn 3, the main ligands of these receptors, may also have a role (Kuperman et al., 2010).

\subsection{Brain targets}

The level of CRH is elevated in response to stress not only in the PVN, but also in many brain areas involved in the regulation of feeding behavior. E.g. the VMH is classically referred to as the satiety center because its electrical stimulation leads to inhibition of food intake. CRH-2 receptor mRNA has been demonstrated to be highly expressed here (Lovenberg et al., 1995). Basolateral amygdala mediates $\mathrm{CRH}$-induced anorexia through $\mathrm{CRH}-1$ receptors (Jochman et al., 2005), while lateral septum and BNST through the CRH-2 receptor (Ohata and Shibasaki, 2011; Smagin et al., 1998). However, pharmacological and neuromorphological studies have demonstrated that Ucn-3 rather than CRH is the most potent and specific endogenous ligand for $\mathrm{CRH}-2$ receptor (Chen et al., 2010). In rats Ucn-3, injected into the $\mathrm{VMH}$, significantly reduced the food intake without affecting the HPA axis activity (Chen et al., 2010; Kuperman and Chen, 2008).

Nevertheless, knocking out the CRH-1 or CRH-2 receptor does not influence body weight or basal food intake (Preil et al., 2001). Thus, neither $\mathrm{CRH}$ receptor is likely to play a critical role in the basal regulation of body weight and the total amount of food intake. Rather, they may be involved in biphasic control of Ucn-mediated feeding behavior (Bradbury et al., 2000; Coste et al., 2000), as well as in cross-talk among central leptin, melanocortin and CRH 
467 pathways (Marsh et al., 1999; Uehara et al., 1998). This assump468 tion is supported by the fact that leptin up-regulates VMH CRH-2 469 receptor mRNA levels (Huang et al., 2006) mediating anorexigenic 470 effects of CRH and/or Ucns.

\section{$471 \quad$ 5.2. Indirect effects}

CRH may exert orexigenic effect through elevation of plasma GC concentrations. In line with this idea CRH infusion to healthy, non-obese adults resulted in elevated cortisol levels parallel with an increase in food-intake (George et al., 2010).

On the other hand, CRH may interact with orexigenic peptides. CRH inhibits NPY synthesis and release (White, 1993) and decreases NPY-induced food intake (Tempel and Leibowitz, 1994). Several studies indicate that nociceptin/orphanin acts in the BNST as a functional antagonist of $\mathrm{CRH}$ to inhibit its anorexigenic effect (Ciccocioppo et al., 2004).

\section{Conclusions}

In both animals and humans, stress affects food intake in a bidirectional way depending on stress intensity and environmental factors (Table 1 ). Any stress activates both anorexigenic and orexigenic pathways (Fig. 1 and Graphical abstract). Balance between the pathways shifts to anorexigenic if high calorie food is not available (it is not clear how), and shifts to orexigenic if high calorie food is available, obviously due to reduced aversiveness of stress and rewarding potential of the food. Thus, stress may potentiate the development of obesity and other aspects of metabolic syndrome only in animals and people, which fed a high calorie, fat and sugar diet. This is important since behavioral modification - do not eat in excess - is likely to have a major epidemiological impact on the obesity epidemic. In this context stress is diabetogenic only in combination with a special diet and intermittent stressors are rather antidiabetogenics, thus beneficial. In human, stress-induced excessive GC production leads to search for palatable food because of its rewarding, stress-reducing potentials.

\section{Conflict of interest statement}

The authors declare that there are no conflicts of interest.

\section{Role of the funding source}

This work was supported by Russian Fund of Basic Researches, grant No. 11-04-01956 in the writing of the report.

\section{References}

Adam, T.C., Epel, E.S., 2007. Stress, eating and the reward system. Physiology and Behavior 91, 449-458.

Ahn, S., Phillips, A.G., 2012. Repeated cycles of restricted food intake and binge feeding disrupt sensory-specific satiety in the rat. Behavioural Brain Research 231, 279-285.

Al-Barazanji, K.A., Miller, J.E., Rice, S.Q., Arch, J.R., Chambers, J.K., 2001. C-terminal fragments of ACTH stimulate feeding in fasted rats. Hormone and Metabolic Research 33, 480-485.

Auvinen, H.E., Romijn, J.A., Biermasz, N.R., Havekes, L.M., Smit, J.W., Rensen, P.C., Pereira, A.M., 2011. Effects of high fat diet on the basal activity of the hypothalamus-pituitary-adrenal axis in mice: a systematic review. Hormone and Metabolic Research 43, 899-906.

Barat, P., Duclos, M., Gatta, B., Roger, P., Mormede, P., Moisan, M.P., 2005. Corticosteroid binding globulin gene polymorphism influences cortisol driven fat distribution in obese women. Obesity Research 13, 1485-1490.

Bartolomucci, A., et al., 2009. Metabolic consequences and vulnerability to dietinduced obesity in male mice under chronic social stress. PLoS ONE 4, e4331.

Bates, H.E., Sirek, A., Kiraly, M.A., Yue, J.T., Riddell, M.C., Matthews, S.G., Vranic, M., 2008a. Adaptation to intermittent stress promotes maintenance of beta-cell compensation: comparison with food restriction. American Journal of Physiology. Endocrinology and Metabolism 295, E947-E958.
Bates, H.E., Sirek, A.S., Kiraly, M.A., Yue, J.T., Goche Montes, D., Matthews, S.G., Vranic, M., 2008b. Adaptation to mild, intermittent stress delays development of hyperglycemia in the Zucker diabetic fatty rat independent of food intake: role of habituation of the hypothalamic-pituitary-adrenal axis. Endocrinology 149, 2990-3001.

Bazhan, N.V., Makarova, E.N., Shevchenko, A., Iakovleva, T.V., 2007. Repeating of emotional stress prevents development of melanocortin obesity and type 2 diabetes in the mice with the Agouti yellow mutation. Rossiiskii Fiziologicheskii Zhurnal Imeni I. M. Sechenova 93, 1237-1244.

Beck, B., Bossenmeyer-Pourie, C., Pourie, G., 2010. Association of neuropeptide W, but not obestatin, with energy intake and endocrine status in Zucker rats. A new player in long-term stress-feeding interactions. Appetite 55, 319-324.

Bernier, N.J., 2006. The corticotropin-releasing factor system as a mediator of the appetite-suppressing effects of stress in fish. General and Comparative Endocrinology 146, 45-55.

Berridge, K.C., 2009. 'Liking' and 'wanting' food rewards: brain substrates and roles in eating disorders. Physiology and Behavior 97, 537-550.

Bjorntorp, P., 2001. Do stress reactions cause abdominal obesity and comorbidities? Obesity Reviews 2, 73-86.

Blazquez Fernandez, E., 2003. Molecular aspects of a hypothalamic glucose sensor system and their implications in the control of food intake. Anales de la Rea Academia Nacional de Medicina 120, 513-522.

Bradbury, M.J., McBurnie, M.I., Denton, D.A., Lee, K.F., Vale, W.W., 2000. Modulation of urocortin-induced hypophagia and weight loss by corticotropin-releasing factor receptor 1 deficiency in mice. Endocrinology 141, 2715-2724.

Burdakov, D., Luckman, S.M., Verkhratsky, A., 2005. Glucose-sensing neurons of the hypothalamus. Philosophical Transactions of the Royal Society of London, Series B: Biological Sciences 360, 2227-2235.

Caballero, B., 2007. The global epidemic of obesity: an overview. Epidemiologic Reviews 29, 1-5.

Cavagnini, F., Croci, M., Putignano, P., Petroni, M.L., Invitti, C., 2000. Glucocorticoids and neuroendocrine function. International Journal of Obesity and Related Metabolic Disorders 24 (Suppl 2), S77-S79.

Chagra, S.L., Zavala, J.K., Hall, M.V., Gosselink, K.L., 2011. Acute and repeated restrain differentially activate orexigenic pathways in the rat hypothalamus. Regulatory Peptides 167, 70-78.

Charrier, C., Chigr, F., Tardivel, C., Mahaut, S., Jean, A., Najimi, M., Moyse, E., 2006. $\mathrm{BDNF}$ regulation in the rat dorsal vagal complex during stress-induced anorexia. Brain Research 1107, 52-57.

Chavez, M., Seeley, R.J., Green, P.K., Wilkinson, C.W., Schwartz, M.W., Woods, S.C. 1997. Adrenalectomy increases sensitivity to central insulin. Physiology and Behavior 62, 631-634.

Chen, P., Vaughan, J., Donaldson, C., Vale, W., Li, C., 2010. Injection of urocortin 3 into the ventromedial hypothalamus modulates feeding, blood glucose levels, and hypothalamic POMC gene expression but not the HPA axis. American Journa of Physiology. Endocrinology and Metabolism 298, E337-E345.

Chrousos, G.P., 2000. The role of stress and the hypothalamic-pituitary-adrenal axis in the pathogenesis of the metabolic syndrome: neuro-endocrine and target tissue-related causes. International Journal of Obesity and Related Metabolic Disorders 24 (Suppl. 2), S50-S60.

Ciccocioppo, R., Cippitelli, A., Economidou, D., Fedeli, A., Massi, M., 2004. Nociceptin/orphanin FQ acts as a functional antagonist of corticotropin-releasing factor to inhibit its anorectic effect. Physiology and Behavior 82, 63-68.

Conrad, C.D., McEwen, B.S., 2000. Acute stress increases neuropeptide Y mRNA within the arcuate nucleus and hilus of the dentate gyrus. Brain Research. Molecular Brain Research 79, 102-109.

Coste, S.C., et al., 2000. Abnormal adaptations to stress and impaired cardiovascular function in mice lacking corticotropin-releasing hormone receptor-2. Nature Genetics 24, 403-409.

Cullen, M.J., Ling, N., Foster, A.C., Pelleymounter, M.A., 2001. Urocortin, corticotropin releasing factor-2 receptors and energy balance. Endocrinology 142 992-999.

Dagogo-Jack, S., Selke, G., Melson, A.K., Newcomer, J.W., 1997. Robust leptin secretory responses to dexamethasone in obese subjects. Journal of Clinical Endocrinology and Metabolism 82, 3230-3233.

Dallman, M.F., 1993. Stress update. Adaptation of the hypothalamic-pituitaryadrenal axis to chronic stress. Trends in Endocrinology and Metabolism 4, 62-69.

Dallman, M.F., 2010. Stress-induced obesity and the emotional nervous system. Trends in Endocrinology and Metabolism 21, 159-165.

Dallman, M.F., Akana, S.F., Strack, A.M., Hanson, E.S., Sebastian, R.J., 1995. The neural network that regulates energy balance is responsive to glucocorticoids and insulin and also regulates HPA axis responsivity at a site proximal to CRF neurons. Annals of the New York Academy of Sciences 771, 730-742.

Dallman, M.F., Pecoraro, N.C., la Fleur, S.E., 2005. Chronic stress and comfort foods: self-medication and abdominal obesity. Brain, Behavior, and Immunity $19,275-280$.

Dallman, M.F., et al., 2006. Glucocorticoids, chronic stress, and obesity. Progress in Brain Research 153, 75-105.

De Souza, J., Butler, A.A., Cone, R.D., 2000. Disproportionate inhibition of feeding in $\mathrm{A}(\mathrm{y})$ mice by certain stressors: a cautionary note. Neuroendocrinology 72 $126-132$.

Dinan, T.G., Cryan, J.F., 2012. Regulation of the stress response by the gut microbiota: implications for psychoneuroendocrinology. Psychoneuroendocrinology 37, 1369-1378.

Drapeau, V., Therrien, F., Richard, D., Tremblay, A., 2003. Is visceral obesity a physiological adaptation to stress? Panminerva Medica 45, 189-195. 
Epel, E.S., McEwen, B., Seeman, T., Matthews, K., Castellazzo, G., Brownell, K.D., Bell, J., Ickovics, J.R., 2000. Stress and body shape: stress-induced cortisol secretion is consistently greater among women with central fat. Psychosomatic Medicine 62, 623-632.

Fekete, E.M., Zorrilla, E.P., 2007. Physiology, pharmacology, and therapeutic relevance of urocortins in mammals: ancient CRF paralogs. Frontiers in Neuroendocrinology 28, 1-27.

Fetissov, S.O., Hallman, J., Oreland, L., Af Klinteberg, B., Grenback, E., Hulting, A.L., Hokfelt, T., 2002. Autoantibodies against alpha-MSH, ACTH, and LHRH in anorexia and bulimia nervosa patients. Proceedings of the National Academy of Sciences of the United States of America 99, 17155-17160.

Foster, M.T., Warne, J.P., Ginsberg, A.B., Horneman, H.F., Pecoraro, N.C., Akana, S.F., Dallman, M.F., 2009. Palatable foods, stress, and energy stores sculpt corticotropin-releasing factor, adrenocorticotropin, and corticosterone concentrations after restraint. Endocrinology 150, 2325-2333.

Fryer, S., Waller, G., Kroese, B.S., 1997. Stress, coping, and disturbed eating attitudes in teenage girls. International Journal of Eating Disorders 22, 427-436.

Gantz, I., Konda, Y., Tashiro, T., Shimoto, Y., Miwa, H., Munzert, G., Watson, S.J., DelValle, J., Yamada, T., 1993. Molecular cloning of a novel melanocortin receptor Journal of Biological Chemistry 268, 8246-8250.

George, S.A., Khan, S., Briggs, H., Abelson, J.L., 2010. CRH-stimulated cortisol release and food intake in healthy, non-obese adults. Psychoneuroendocrinology 35 , 607-612.

Gibson, E.L., 2006. Emotional influences on food choice: sensory, physiological and psychological pathways. Physiology and Behavior 89, 53-61.

Goebel, M., Stengel, A., Wang, L., Tache, Y., 2009. Restraint stress activates nesfatin1-immunoreactive brain nuclei in rats. Brain Research 1300, 114-124.

Green, M.K., Devine, D.P., 2009. Nociceptin/orphanin FQ and NOP receptor gene regulation after acute or repeated social defeat stress. Neuropeptides 43,507-514

Greeno, C.G., Wing, R.R., 1994. Stress-induced eating. Psychological Bulletin 115, 444-464.

Gyengesi, E., Liu, Z.W., D’Agostino, G., Gan, G., Horvath, T.L., Gao, X.B., Diano, S., 2010. Corticosterone regulates synaptic input organization of POMC and NPY/AgRP neurons in adult mice. Endocrinology 151, 5395-5402.

Harris, R.B., Zhou, J., Shi, M., Redmann, S., Mynatt, R.L., Ryan, D.H., 2001. Overexpression of agouti protein and stress responsiveness in mice. Physiology and Behavior 73, 599-608.

Holsen, L.M., Lawson, E.A., Blum, J., Ko, E., Makris, N., Fazeli, P.K., Klibanski, A., Goldstein, J.M., 2012. Food motivation circuitry hypoactivation related to hedonic and nonhedonic aspects of hunger and satiety in women with active anorexia nervosa and weight-restored women with anorexia nervosa. Journal of Psychiatry and Neuroscience 37, 322-332.

Huang, Q., Timofeeva, E., Richard, D., 2006. Regulation of corticotropin-releasing factor and its types 1 and 2 receptors by leptin in rats subjected to treadmill running-induced stress. Journal of Endocrinology 191, 179-188.

Iwen, K.A., Senyaman, O., Schwartz, A., Drenckhan, M., Meier, B., Hadaschik, D., Klein, J., 2008. Melanocortin crosstalk with adipose functions: ACTH directly induces insulin resistance, promotes a pro-inflammatory adipokine profile and stimulates UCP-1 in adipocytes. Journal of Endocrinology 196, 465-472.

Jacobson, L., 1999. Glucocorticoid replacement, but not corticotropin-releasing hormone deficiency, prevents adrenalectomy-induced anorexia in mice. Endocrinology 140, 310-317.

Jochman, K.A., Newman, S.M., Kalin, N.H., Bakshi, V.P., 2005. Corticotropin-releasing factor-1 receptors in the basolateral amygdala mediate stress-induced anorexia. Behavioral Neuroscience 119, 1448-1458.

Joyner, J.M., Hutley, L.J., Bachmann, A.W., Torpy, D.J., Prins, J.B., 2003. Greater replication and differentiation of preadipocytes in inherited corticosteroidbinding globulin deficiency. American Journal of Physiology. Endocrinology and Metabolism 284, E1049-E1054.

Kai, K., Morimoto, I., Morita, E. Okada, Y, Yamamoto, S., Kanda, K., Uriu, K, Eto, S., 2000. Environmental stress modifies glycemic control and diabetes onset in type 2 diabetes prone Otsuka Long Evans Tokushima Fatty (OLETF) rats. Physiology and Behavior 68, 445-452.

Kang, K.S., Shimizu, K., Azuma, M., Ui, Y., Nakamura, K., Uchiyama, M., Matsuda, K., 2011. Gonadotropin-releasing hormone II (GnRH II) mediates the anorexigenic actions of alpha-melanocyte-stimulating hormone (alpha-MSH) and corticotropin-releasing hormone $(\mathrm{CRH})$ in goldfish. Peptides 32, 31-35.

Kas, M.J., Bruijnzeel, A.W., Haanstra, J.R., Wiegant, V.M., Adan, R.A., 2005. Differential regulation of agouti-related protein and neuropeptide $Y$ in hypothalamic neurons following a stressful event. Journal of Molecular Endocrinology 35, 159-164.

Kask, A., Schioth, H.B., Mutulis, F., Wikberg, J.E., Rago, L., 2000. Anorexigenic cocaineand amphetamine-regulated transcript peptide intensifies fear reactions in rats. Brain Research 857, 283-285.

Kelley, D.E., Wing, R., Buonocore, C., Sturis, J., Polonsky, K., Fitzsimmons, M., 1993. Relative effects of calorie restriction and weight loss in noninsulindependent diabetes mellitus. Journal of Clinical Endocrinology and Metabolism 77, 1287-1293.

Kiba, T., 2004. Relationships between the autonomic nervous system and the pancreas including regulation of regeneration and apoptosis: recent developments. Pancreas 29, e51-e58.

Kiefer, F., Grosshans, M., 2009. What can addiction research contribute towards the understanding of obesity? Nervenarzt 80, 1040-1049.

King, B.M., Smith, R.L., 1985. Hypothalamic obesity after hypophysectomy or adrenalectomy: dependence on corticosterone. American Journal of Physiology 249, R522-R526.
Konturek, P.C., Brzozowski, T., Konturek, S.J., 2011. Stress and the gut: pathophysiology, clinical consequences, diagnostic approach and treatment options. Journal of Physiology and Pharmacology 62, 591-599.

Krahn, D.D., Gosnell, B.A., 1989. Corticotropin-releasing hormone: possible role in eating disorders. Psychiatric Medicine 7, 235-245.

Krahn, D.D., Gosnell, B.A., Majchrzak, M.J., 1990. The anorectic effects of CRH and restraint stress decrease with repeated exposures. Biological Psychiatry 27, 1094-1102.

Krude, H., Biebermann, H., Luck, W., Horn, R., Brabant, G., Gruters, A., 1998. Severe early-onset obesity, adrenal insufficiency and red hair pigmentation caused by POMC mutations in humans. Nature Genetics 19, 155-157.

Krysiak, R., Obuchowicz, E., Herman, Z.S., 1999. Interactions between the neuropeptide Y system and the hypothalamic-pituitary-adrenal axis. European Journal of Endocrinology/European Federation of Endocrine Societies 140, 130-136.

Kuperman, Y., Chen, A., 2008. Urocortins: emerging metabolic and energy homeostasis perspectives. Trends in Endocrinology and Metabolism 19, 122-129.

Kuperman, Y., Issler, O., Regev, L., Musseri, I., Navon, I., Neufeld-Cohen, A., Gil, S., Chen, A., 2010. Perifornical urocortin-3 mediates the link between stressinduced anxiety and energy homeostasis. Proceedings of the National Academy of Sciences of the United States of America 107, 8393-8398.

Kuroshima, A., Konno, N., Doi, K., Itoh, S., 1968. Effect of corticotropin and adrenocortical hormone on the blood flow through brown adipose tissue in the rat Japanese Journal of Physiology 18, 446-452.

la Fleur, S.E., Houshyar, H., Roy, M., Dallman, M.F., 2005. Choice of lard, but not total lard calories, damps adrenocorticotropin responses to restraint. Endocrinology 146, 2193-2199.

Leal-Cerro, A., Soto, A., Martinez, M.A., Dieguez, C., Casanueva, F.F., 2001. Influence of cortisol status on leptin secretion. Pituitary 4, 111-116.

Leibowitz, S.F., Wortley, K.E., 2004. Hypothalamic control of energy balance: different peptides, different functions. Peptides 25, 473-504.

Lesault, A., Elchinger, B., Desbals, B., 1991. Circadian variations and extraadrenal effect of ACTH on insulinemia in rabbit. Hormone and Metabolic Research 23, 461-464.

Levin, B.E., Richard, D., Michel, C., Servatius, R., 2000. Differential stress responsivity in diet-induced obese and resistant rats. American Journal of Physiology. Regulatory, Integrative and Comparative Physiology 279, R1357-R1364.

Lewis, G.P., Matthews, J., 1968. The mobilization of free fatty acids from rabbit adipose tissue in situ. British Journal of Pharmacology 34, 564-578.

Liu, J., Garza, J.C., Truong, H.V., Henschel, J., Zhang, W., Lu, X.Y., 2007. The melanocortinergic pathway is rapidly recruited by emotional stress and contributes to stress-induced anorexia and anxiety-like behavior. Endocrinology 148, 5531-5540.

Lovenberg, T.W., Chalmers, D.T., Liu, C., De Souza, E.B., 1995. CRF2 alpha and CRF2 beta receptor mRNAs are differentially distributed between the rat central nervous system and peripheral tissues. Endocrinology 136, 4139-4142.

Macho, L., Fickova, M., Zorad, S., Kvetnansky, R., 1999. Changes of insulin binding in rat tissues after exposure to stress. Physiological Research 48, 51-58.

Marsh, D.J., Hollopeter, G., Huszar, D., Laufer, R., Yagaloff, K.A., Fisher, S.L., Burn, P., Palmiter, R.D., 1999. Response of melanocortin-4 receptor-deficient mice to anorectic and orexigenic peptides. Nature Genetics 21, 119-122.

McKibbin, P.E., Cotton, S.J., McCarthy, H.D., Williams, G., 1992. The effect of dexamethasone on neuropeptide $Y$ concentrations in specific hypothalamic regions. Life Sciences 51, 1301-1307.

Miell, J.P., Englaro, P., Blum, W.F., 1996. Dexamethasone induces an acute and sustained rise in circulating leptin levels in normal human subjects. Hormone and Metabolic Research 28, 704-707.

Moore, C.J., Cunningham, S.A., 2012. Social position, psychological stress, and obesity: a systematic review. Journal of the Academy of Nutrition and Dietetics 112 , 518-526.

Nativio, P., Pascale, E., Maffei, A., Scaccianoce, S., Passarelli, F., 2011. Effect of stress on hippocampal nociceptin expression in rat. Stress.

Newcomer, J.W., Selke, G., Melson, A.K., Gross, J., Vogler, G.P., Dagogo-Jack, S., 1998 Dose-dependent cortisol-induced increases in plasma leptin concentration in healthy humans. Archives of General Psychiatry 55, 995-1000.

Nieuwenhuizen, A.G., Rutters, F., 2008. The hypothalamic-pituitary-adrenal-axis in the regulation of energy balance. Physiology and Behavior 94, 169-177.

Nonogaki, K., 2000. New insights into sympathetic regulation of glucose and fat metabolism. Diabetologia 43, 533-549.

Nye, E.J., Bornstein, S.R., Grice, J.E., Tauchnitz, R., Hockings, G.I., Strakosch, C.R., Jackson, R.V., Torpy, D.J., 2000. Interactions between the stimulated hypothalamic-pituitary-adrenal axis and leptin in humans. Journal of Neuroendocrinology 12, 141-145.

O'Connor, D.B., Conner, M., 2011. Effects of Stress on Eating Behavior. The Handbook of Stress Science. Springer Publishing Company, Contrada and Baum.

Ohata, H., Shibasaki, T., 2011. Involvement of CRF2 receptor in the brain regions in restraint-induced anorexia. Neuroreport 22, 494-498.

Olszewski, P.K., Levine, A.S., 2004. Minireview: characterization of influence of central nociceptin/orphanin FQ on consummatory behavior. Endocrinology 145 2627-2632.

Ortolani, D., Oyama, L.M., Ferrari, E.M., Melo, L.L., Spadari-Bratfisch, R.C., 2011. Effects of comfort food on food intake, anxiety-like behavior and the stress response in rats. Physiology and Behavior 103, 487-492.

Palkovits, M., 2003. Hypothalamic regulation of food intake. Ideggyogy Sz 56, 288-302. 
Pecoraro, N., Reyes, F., Gomez, F., Bhargava, A., Dallman, M.F., 2004. Chronic stress promotes palatable feeding, which reduces signs of stress: feedforward and feedback effects of chronic stress. Endocrinology 145, 3754-3762.

Pedersen, R., Andersen, A.D., Molbak, L., Stagsted, J., Boye, M., 2013. Changes in the gut microbiota of cloned and non-cloned control pigs during development of obesity: gut microbiota during development of obesity in cloned pigs. BMC Microbiology 13, 30.

Piazza, P.V., Le Moal, M., 1997. Glucocorticoids as a biological substrate of reward: physiological and pathophysiological implications. Brain Research. Brain Research Reviews 25, 359-372.

Preil, J., et al., 2001. Regulation of the hypothalamic-pituitary-adrenocortical system in mice deficient for CRH receptors 1 and 2. Endocrinology 142, 4946-4955.

Pritchard, L.E., Oliver, R.L., McLoughlin, J.D., Birtles, S., Lawrence, C.B., Turnbull, A.V., White, A., 2003. Proopiomelanocortin-derived peptides in rat cerebrospinal fluid and hypothalamic extracts: evidence that secretion is regulated with respect to energy balance. Endocrinology 144, 760-766.

Rasmusson, A.M., Schnurr, P.P., Zukowska, Z., Scioli, E., Forman, D.E., 2010. Adaptation to extreme stress: post-traumatic stress disorder, neuropeptide $\mathrm{Y}$ and metabolic syndrome. Experimental Biology and Medicine (Maywood, NJ) 235, 1150-1162.

Rosmond, R., 2003. Stress induced disturbances of the HPA axis: a pathway to type 2 diabetes? Medical Science Monitor 9, RA35-RA39.

Rowland, N.E., Antelman, S.M., 1976. Stress-induced hyperphagia and obesity in rats: a possible model for understanding human obesity. Science 191, 310-312.

Ryan, K.K., Woods, S.C., Seeley, R.J., 2012. Central nervous system mechanisms linking the consumption of palatable high-fat diets to the defense of greater adiposity. Cell Metabolism 15, 137-149.

Rybkin, I.I., Zhou, Y., Volaufova, J., Smagin, G.N., Ryan, D.H., Harris, R.B., 1997. Effect of restraint stress on food intake and body weight is determined by time of day. American Journal of Physiology 273, R1612-R1622.

Santana, P., Akana, S.F., Hanson, E.S., Strack, A.M., Sebastian, R.J., Dallman, M.F., 1995 Aldosterone and dexamethasone both stimulate energy acquisition whereas only the glucocorticoid alters energy storage. Endocrinology 136, 2214-2222.

Sapolsky, R.M., Romero, L.M., Munck, A.U., 2000. How do glucocorticoids influence stress responses? Integrating permissive, suppressive, stimulatory, and preparative actions. Endocrine Reviews 21, 55-89.

Savontaus, E., Conwell, I.M., Wardlaw, S.L., 2002. Effects of adrenalectomy on AGRP, POMC, NPY and CART gene expression in the basal hypothalamus of fed and fasted rats. Brain Research 958, 130-138.

Schulz, C., Paulus, K., Lobmann, R., Dallman, M., Lehnert, H., 2010. Endogenous ACTH, not only alpha-melanocyte-stimulating hormone, reduces food intake mediated by hypothalamic mechanisms. American Journal of Physiology. Endocrinology and Metabolism 298, E237-E244.

Schwartz, M.W., Woods, S.C., Porte Jr., D., Seeley, R.J., Baskin, D.G., 2000. Central nervous system control of food intake. Nature 404, 661-671.

Seematter, G., Guenat, E., Schneiter, P., Cayeux, C., Jequier, E., Tappy, L., 2000. Effects of mental stress on insulin-mediated glucose metabolism and energy expenditure in lean and obese women. American Journal of Physiology. Endocrinology and Metabolism 279, E799-E805.

Shimizu, N., Oomura, Y., Kai, Y., 1989. Stress-induced anorexia in rats mediated by serotonergic mechanisms in the hypothalamus. Physiology and Behavior 46, 835-841.

Slieker, L.J., Sloop, K.W., Surface, P.L., Kriauciunas, A., LaQuier, F., Manetta, J., BueValleskey, J., Stephens, T.W., 1996. Regulation of expression of ob mRNA and protein by glucocorticoids and cAMP. Journal of Biological Chemistry 271, 5301-5304.

Smagin, G.N., Howell, L.A., Ryan, D.H., De Souza, E.B., Harris, R.B., 1998. The role of CRF2 receptors in corticotropin-releasing factor- and urocortin-induced anorexia. Neuroreport 9, 1601-1606.

Solomon, M.B., Jones, K., Packard, B.A., Herman, J.P., 2010. The medial amygdala modulates body weight but not neuroendocrine responses to chronic stress. Journal of Neuroendocrinology 22, 13-23.

Spirovski, M.Z., Kovacev, V.P., Spasovska, M., Chernick, S.S., 1975. Effect of ACTH on lipolysis in adipose tissue of normal and adrenalectomized rats in vivo. American Journal of Physiology 228, 382-385.

Stamp, J.A., Mashoodh, R., van Kampen, J.M., Robertson, H.A., 2008. Food restriction enhances peak corticosterone levels, cocaine-induced locomotor activity, and DeltaFosB expression in the nucleus accumbens of the rat. Brain Research 1204, 94-101.
Stengel, A., Goebel, M., Tache, Y., 2011. Nesfatin-1: a novel inhibitory regulator of food intake and body weight. Obesity Reviews 12, 261-271.

Sudo, N., 2012. Role of microbiome in regulating the HPA axis and its relevance to allergy. Chemical Immunology and Allergy 98, 163-175.

Surwit, R.S., Schneider, M.S., Feinglos, M.N., 1992. Stress and diabetes mellitus Diabetes Care 15, 1413-1422.

Tataranni, P.A., Larson, D.E., Snitker, S., Young, J.B., Flatt, J.P., Ravussin, E., 1996. Effects of glucocorticoids on energy metabolism and food intake in humans. American Journal of Physiology 271, E317-E325.

Tataranni, P.A., Pratley, R., Maffei, M., Ravussin, E., 1997. Acute and prolonged administration of glucocorticoids (methylprednisolone) does not affect plasma leptin concentration in humans. International Journal of Obesity and Related Metabolic Disorders 21, 327-330.

Tehrani, A.B., Nezami, B.G., Gewirtz, A., Srinivasan, S., 2012. Obesity and its associated disease: a role for microbiota? Neurogastroenterology and Motility 24 305-311.

Tempel, D.L., Leibowitz, S.F., 1994. Adrenal steroid receptors: interactions with brain neuropeptide systems in relation to nutrient intake and metabolism. Journal of Neuroendocrinology 6, 479-501.

Tempel, D.L., McEwen, B.S., Leibowitz, S.F., 1992. Effects of adrenal steroid agonists on food intake and macronutrient selection. Physiology and Behavior 52, 1161-1166.

Tey, S.L., Brown, R.C., Gray, A.R., Chisholm, A.W., Delahunty, C.M., 2012. Long-term consumption of high energy-dense snack foods on sensory-specific satiety and intake. American Journal of Clinical Nutrition 95, 1038-1047.

Tokuyama, K., Himms-Hagen, J., 1989. Adrenalectomy prevents obesity in glutamate-treated mice. American Journal of Physiology 257, E139-E144.

Torres, S.J., Nowson, C.A., 2007. Relationship between stress, eating behavior, and obesity. Nutrition 23, 887-894.

Uehara, Y., Shimizu, H., Ohtani, K., Sato, N., Mori, M., 1998. Hypothalamic corticotropin-releasing hormone is a mediator of the anorexigenic effect of leptin. Diabetes 47, 890-893.

Vale, W., Spiess, J., Rivier, C., Rivier, J., 1981. Characterization of a 41-residue ovine hypothalamic peptide that stimulates secretion of corticotropin and betaendorphin. Science 213, 1394-1397.

Vinson, G.P., 2009. The adrenal cortex and life. Molecular and Cellular Endocrinology $300,2-6$

Volkow, N.D., Wang, G.J., Fowler, J.S., Telang, F., 2008. Overlapping neuronal circuits in addiction and obesity: evidence of systems pathology. Philosophica Transactions of the Royal Society of London, Series B: Biological Sciences 363 , 3191-3200.

Warne, J.P., 2009. Shaping the stress response: interplay of palatable food choices, glucocorticoids, insulin and abdominal obesity. Molecular and Cellular Endocrinology 300, 137-146.

White, J.D., 1993. Neuropeptide Y: a central regulator of energy homeostasis. Regulatory Peptides 49, 93-107.

Wilding, J.P., Gilbey, S.G., Lambert, P.D., Ghatei, M.A., Bloom, S.R., 1993. Increases in neuropeptide $\mathrm{Y}$ content and gene expression in the hypothalamus of rats treated with dexamethasone are prevented by insulin. Neuroendocrinology 57 , 581-587.

Won, J.C., Jang, P.G., Namkoong, C., Koh, E.H., Kim, S.K., Park, J.Y., Lee, K.U., Kim, M.S., 2009. Central administration of an endoplasmic reticulum stress inducer inhibits the anorexigenic effects of leptin and insulin. Obesity (Silver Spring) 17, 1861-1865.

Xu, L., Bloem, B., Gaszner, B., Roubos, E.W., Kozicz, T., 2010. Stress-related changes in the activity of cocaine- and amphetamine-regulated transcript and nesfatin neurons in the midbrain non-preganglionic Edinger-Westphal nucleus in the rat. Neuroscience 170, 478-488.

Yamano, Y., Yoshioka, M., Toda, Y., Oshida, Y., Chaki, S., Hamamoto, K., Morishima I., 2004. Regulation of CRF, POMC and MC4R gene expression after electrical foot shock stress in the rat amygdala and hypothalamus. Journal of Veterinary Medical Science 66, 1323-1327.

Yayou, K.I., Kitagawa, S., Ito, S., Kasuya, E., Sutoh, M., 2011. Effect of oxytocin, prolactin-releasing peptide, or corticotropin-releasing hormone on feeding behavior in steers. General and Comparative Endocrinology.

York, D.A., 1996. Lessons from animal models of obesity. Endocrinology and Metabolism Clinics of North America 25, 781-800.

Zareian, P., Karimi, M.V., Dorneyani, G., 2011. The comparison of the effects of acute swimming stress on plasma corticosterone and leptin concentration in male and female rats. Acta Medica Iranica 49, 284-287. 